O. V. Bobrov ${ }^{1}$, Cand. Sc. (Tech.), orcid.org/0000-0002-1872-8900, D. V. Tsyplenkov ${ }^{2}$, Cand. Sc. (Tech.), Assoc. Prof., orcid.org/0000-0002-0378-5400,

A. M. Grebeniuk ${ }^{2}$, Cand. Sc. (Tech.), Assoc. Prof., orcid.org/0000-0002-6529-683X,

M.S. Kyrychenko ${ }^{2}$, orcid.org/0000-0003-0615-7589
1 - Rocket-and-Space Engineering College of Oles Honchar Dnipro National University, Dnipro, Ukraine, e-mail: alekseybob@ua.fm

2 - Dnipro University of Technology, Dnipro, Ukraine, email: tsyplenkov.d.v@nmu.one

\title{
JUSTIFICATION OF THE OPTIMUM OPERATION OF ELECTROMECHANICAL SYSTEM FOR PRODUCTION AND DISTRIBUTION OF PRESSURIZED AIR
}

Purpose. To increase the energy efficiency of the electromechanical system of production and distribution of compressed air by applying a new way of controlling the electric drive of the compressor plant.

Methodology. The following methods are used: method of parametric optimization (scanning) - to solve the problem of conditional optimization of the duration of the compressor state on each control cycle, with different charges of compressed air Q; method of approximation of the initial data of the electromechanical system; regression analysis - when constructing a nonlinear dependence of compressor performance and loss of compressed air.

Findings. The reasons of low energy efficiency of electromechanical system for production and distribution of pressurized air, based on the reciprocating compressor, were considered. Correlation and mutual influence of separate system's elements and their modes of operation were analyzed. The analysis of energy dissipation levels in the elements of electromechanical system was carried out to improve the method for controlling the electrical drive of compressor by applying new engineering solutions. Analytical dependences of the efficiency factor on energy dissipation levels in certain elements of the system and its duty parameters with two-step action of compressor output were established. A mathematical model for calculation of the coefficient of efficiency of the electromechanical system was carried out; the optimization problem for the operation parameters was formulated and solved, with certain assumptions and limitations, upon condition of two-step action of the electrical drive of the compressor. The proposed model is distinguished from existing models by the possibility of operation regimes accounting for all elements of the electromechanical system to determine its energy indicator - the coefficient of efficiency. The results of parametric optimization of operational regimes of the electromechanical system for production and distribution of pressurized air, with different levels of pressurized air consumption, were proposed.

Originality. It is proved that with an increase in the performance of air compressors with the proposed method of control, the efficiency of the system increases in comparison with the traditional method for controlling compressors, which increases the energy efficiency of the electromechanical system as a whole.

Practical value. The algorithm of control of compressor power consumption, which reproduces the principle of determining the costs of compressed air on the basis of measuring the speed of pressure change in its receiver, is developed, and it allows predicting the duration of the control cycle.

Keywords: electric drive, the compressor, electromechanical system, pressurized air

Introduction. Providing the pressurized air to consumers is an energy-intense process. The coefficient of efficiency for a compressor plant of pressurized air distribution system is comparably low, that is why the cost of pressurized air production is high.

Systems providing the pressurized air, based on the piston-type compressor plants, hold the specific place. Generally, they are some widespread systems of low efficiency that have one compressor plant and small distribution network. Adjustment of the compressor's efficiency is carried out by the control of the electric drive. These plants, like other similar ones, also have low energy efficiency caused by energy dissipation. A need in reduction of energy dissipation on every process stage arises.

(c) Bobrov O.V., Tsyplenkov D. V., Grebeniuk A. M., Kyrychenko M. S., 2019
Analysis of the recent publications and problem statement. Analysis of the literature indicates that decisions directed towards the improvement of energy efficiency of the pressurized air production, focus on the individual elements of the system (compressor plant, distribution system of pressurized air). These results were not generalized and were not considered in terms of the energy efficiency of the whole process. The investigation of a pressurized air production system, which composes of elements that are correlated and have mutual influence on each other (supply chain, compressor, pneumatic circuit) allows approaching the analysis of consistent electromechanical processes, and proposing technical solution for compressor control, which provides increased energy efficiency of the process as a whole.

Objectives of the article.The aim of this study is to increase the energy efficiency of electromechanical system for production and distribution of pressurized air 
through the application of a new method for controlling the electric drive of the compressor plant.

Presentation of the main research on operation peculiarities of electromechanical system elements. The operational regimes of electromechanical system's elements were examined. The methods for control of operational regime parameters of pressurized air production complex as well as energy dissipation on its elements were analyzed [1, 2].

High energy consumption of the conversion process from the electrical energy into the energy of pressurized air results from a number of important factors. The level of energy dissipation in the elements of the system is primarily caused by features of construction and their operational regimes. It is noteworthy, that the constructions of existing compressor plants and pressurized air distribution systems do not provide the high values of efficiency of the system and need some improvement. At the same time, existing operational regimes of compression plants also should be improved. Proceeding on the position that these plants have electric drives, there is a need to develop methods for controlling the electromotor in order to improve the energy efficiency of processes proceeding in these plants.

Scientific research studies concerning determination of energy dissipation in separate parts of the system have been conducted by outstanding scientists. Analyzing these works, we got the conclusion that they for the most part are focused on the definition of energy dissipation coming from the changes of mechanical parameters. Operation regimes of electric drive were not analyzed at all, or analysis was simplified, with the introduction of some significant assumptions. Another feature of the studies, held in this area, is that the definition of energy effective operational regimes is carried out without operational links of separate elements of complicated system (power supply chain, compressor, distribution system of pressurized air), that is why optimal operation regimes of separate elements cannot be considered optimal for the system in a whole. There is a need for optimization of operational regimes of this system in order to achieve the maximum energy efficiency. Based on the fact that the energy efficiency of the process mostly depends on the regulation of the compressor's effectiveness, the most common methods for regulation involving the use of mechanical devices were considered as well as different methods for controlling the electrical drive. Advantages and disadvantages of these methods were disclosed.

This research deals with systems for pressurized air production, which are based on piston-type compressor plants. These compressors are widely applied in industry and agriculture through its ability to solve a substantial number of existing problems, simple construction and high reliability. Typically, they use two-step action of the compressor's effectiveness that provides periodic cycling of the compressor's electromotor to increase the pressure on the receiver. During the consumption of pressurized air, the pressure varies between maximum $P_{\max }$ and minimum $P_{\min }$ values. Accepted limits of pressure $P_{\min }$ and $P_{\max }$ are denoted, on the basis of technical characteristics of pressurized air consumers. It is clear that such method for productivity regulation is caused by the need to ensure operational characteristics of consumers and is not intended to increase energy efficiency of the process. The authors seize the room for perfection of such method for controlling the compressor's electric drive by introduction of new technical solutions, which decrease energy dissipation [2, 3].

The analysis of energy dissipation in the elements of the electromechanical system was carried out in order to:

- determine a list of the operational parameters that have a significant impact on the efficiency of the whole system;

- establish analytical correlations, linking the level of energy dissipation in separate elements of the system with determined parameters;

- make quantitative assessment of energy dissipation in separate elements of the system, which will identify the most energy-intensive parts of total energy dissipation.

The analysis shows that the main parameters that significantly affect the level of energy dissipation in all elements of the system are the pressure in the receiver of compressor $P_{2}$ and the level pressurized air consumption of pneumatic receptors $Q$. The value of $Q$ depends on the voltage level of pneumatic circuit and therefore may be considered as a parameter that cannot be regulated. The value of $P_{2}$ can be changed during controlling of the compressor's electric drive and therefore can be considered as a controlled parameter [4, 5].

Analytical correlations linking the level of energy dissipation in separate elements of the system with operational parameters at two-step action were established. At determining correlations, the following assumptions were considered:

- voltage supply of asynchronous motor is constant ( $U=$ constant);

- efficiency of asynchronous drive of compressors in the process remains almost unchanged;

- influence of air-intake temperature on power consumption is considered insignificant;

- calculation of the operational parameters is performed for $20^{\circ} \mathrm{C}\left(T_{1}=20^{\circ} \mathrm{C}\right)$.

The following components of energy dissipation were determined:

- real energy dissipation in electrical network

$$
\begin{gathered}
\Delta E_{e m}=t_{1} \sum_{i=0}^{m} 3 r_{0} l \times \\
\times\left(\frac{\left.2\left(\frac{n}{n-1}\right) P_{1} Q_{k o m p}\left(\left(\frac{P_{i_{i+1}}}{P_{1}}\right)^{\frac{n-1}{2 n}}-1\right) \frac{1}{\eta_{\text {mech }} \eta_{p o l} \eta_{m}}\right)^{2}}{\sqrt{3} U \cos \varphi},\right.
\end{gathered}
$$

where $r_{0}$ is electrical resistivity of conductor, Ohm $/ \mathrm{km} ; l$ is the length of the line, $\mathrm{km} ; t_{1}$ is duration of pressurized air pumping, hours; $P_{1}$ is pressure, $\mathrm{Pa} ; Q_{k o m p}$ is volumetric effectiveness during pumping, $\mathrm{m}^{3} / \mathrm{s} ; n$ is the polytropic coefficient for piston-type compressors; $\eta_{m}$ is the coefficient of motor efficiency; $\eta_{p o l}$ is indicated efficiency of polytropic compression process; $\eta_{\text {mech }}$ is the me- 
chanical coefficient of efficiency that takes into account dissipations from friction of crank mechanism and the piston of compressor; $U$ is voltage of power supply; $P_{2}$ is pressure in the pneumatic circuit, $\mathrm{Pa} ; m$ is the number of iterations during the incensement of pressure;

- energy dissipation in asynchronous motor and compressor plant

$$
\begin{gathered}
\Delta E_{A M}=t_{1} \sum_{i=0}^{m} 2\left(\frac{n}{n-1}\right) P_{1} Q_{k o m p}\left(\left(\frac{P_{2_{i+1}}}{P_{1}}\right)^{\frac{n-1}{2 n}}-1\right) \frac{1}{\eta_{\text {mech }} \eta_{p o l} \eta_{m}}- \\
-t_{1} \sum_{i=0}^{m} P_{2_{i+1}}\left(B_{0}+B_{1} e^{\frac{-P_{2 i+1}}{B_{2}}}\right),
\end{gathered}
$$

where $B_{0}, B_{1}, B_{2}$ are estimated coefficients of the compressor's productivity;

- energy dissipation in the piping system for pressurized air (during pumping of pressurized air)

$$
\Delta E_{T N}=t_{1} \sum_{i=0}^{m} P_{2_{i+1}}\left(C_{0}+C_{1} e^{\frac{-P_{2_{i+1}}}{C_{2}}}\right),
$$

where $C_{0}, C_{1}, C_{2}$ are estimated coefficients of pressurized air loses in pneumatic circuit;

- energy dissipation in the piping system for pressurized air (during purging of pressurized air)

$$
\Delta E_{T S}=t_{2} \sum_{i=m}^{k} P_{2_{i+1}}\left(C_{0}+C_{1} e^{\frac{-P_{2_{i+1}}}{C_{2}}}\right),
$$

where $t_{2}$ is duration of pressurized air purging, $\mathrm{h} ; k$ is the total number of iterations.

The level of energy dissipation in the elements of the system was analyzed (Fig. 1).

The analysis of energy dissipation in the elements of the system shows that the operating conditions of electromechanical system with small electrical network pneumatic circuit has the biggest values of dissipation in the system, \%. A lower level of dissipation is observed in the "drive - compressor" system, and there is some insignificant dissipation in the circuit.

In the process of changing the consumption level of pressurized air $Q$ it is possible to change the upper limit of pressure $P_{\max }$ in the receiver of the compressor in each cycle of two-step action in order to decrease the level of energy dissipation of the system. [6, 7]. In order to determine the optimal level of $P_{\max }$ the parametric optimization problem was formulated and solved.

The mathematical model for determination of the electromechanical system's efficiency was developed, the problem regime parameters optimization during two-step action of compressor drive was formulated and solved.

$$
\begin{aligned}
& \eta=\frac{t_{1} \sum_{i=0}^{m} 2\left(\frac{n}{n-1}\right) P_{1} Q_{k o m p} D \frac{1}{\eta_{\text {mech }} \eta_{p o l} \eta_{m}}-t_{1}\left(\sum_{i=0}^{m} 2\left(\frac{n}{n-1}\right) P_{1} Q_{k o m p} D \frac{1}{\eta_{\text {mech }} \eta_{\text {pol }} \eta_{m}}-\sum_{i=0}^{m} P_{2_{i+1}} G\right)-t_{1} \sum_{i=0}^{m} P_{2_{i+1}} F-t_{2} \sum_{i=m}^{k} P_{2_{i+1}} F}{2}, \\
& t_{1} \sum_{i=0}^{m} 2\left(\frac{n}{n-1}\right) P_{1} Q_{k o m p} D \frac{1}{\eta_{\text {mech }} \eta_{\text {pol }} \eta_{m}}+t_{1} \sum_{i=0}^{m} 3 r_{0} l\left(\frac{2\left(\frac{n}{n-1}\right) P_{1} Q_{\text {komp }} D \frac{1}{\eta_{\text {mech }} \eta_{\text {pol }} \eta_{m}}}{\sqrt{3} U \cos \varphi}\right)^{2}+\frac{1}{t_{\text {start }}} 3 r_{0} l \int_{0}^{t_{\text {start }}} I_{\text {start }}^{2}(t) d t \\
& \text { where } D=\left(\left(\frac{P_{2_{i+1}}}{P_{1}}\right)^{\frac{n-1}{2 n}}-1\right) ; \quad G=\left(B_{0}+B_{1} e^{\frac{-P_{2 i+1}}{B_{2}}}\right) ; \quad F= \\
& Q=\frac{V}{R T} \cdot \frac{1}{\rho} \cdot \frac{\Delta P_{2_{i}}}{\Delta t}
\end{aligned}
$$$$
=\sum_{i=0}^{m} P_{2_{i+1}}\left(C_{0}+C_{1} e^{\frac{-P_{2_{i+1}}}{C_{2}}}\right) \text {. }
$$

To determine the optimum value of the upper limit of pressure $P_{\max . o p t}$ the parametric optimization problem was formulated [2] and solved. The mathematical model was developed that correlates the value of efficiency $(\eta)$ of the electromechanical system with regulated parameter $P_{\max }$ and the level of pressurized air consumption $Q$, which changes during the operation of the system. The correlation $\eta\left(P_{\max }, Q\right)$ is presented below.

Maximum pressure in the receiver is

$$
P_{\max }=P_{\min }+\sum_{i=0}^{m} \Delta P_{2_{i}},
$$

where $\Delta P_{2_{i}}$ is increase in the pressure in the receiver at step $i$ of the iterative process, $\mathrm{Pa}$.

$$
m=\frac{t_{1}}{\Delta t} ; \quad k=\frac{t_{1}+t_{2}}{\Delta t} ; \quad T_{c}=t_{1}+t_{2},
$$

where $\Delta t$ is an iteration step, $\mathrm{h} ; T_{c}$ is cyclic time, $\mathrm{h}$.

where $T$ is temperature, $\mathrm{K} ; R$ is gas constant for air, $\mathrm{J} /(\mathrm{kg} \times \mathrm{K}) ; \mathrm{r}$ is density of air at normal conditions, $\mathrm{kg} / \mathrm{m}^{3}$; $V$ is volume of pneumatic receptors in the circuit, $\mathrm{m}^{3}$.

The proposed model is distinguished from the existing models by the possibility of operation regimes accounting for all elements of the electromechanical system to determine its energy indicator - the coefficient of ef-

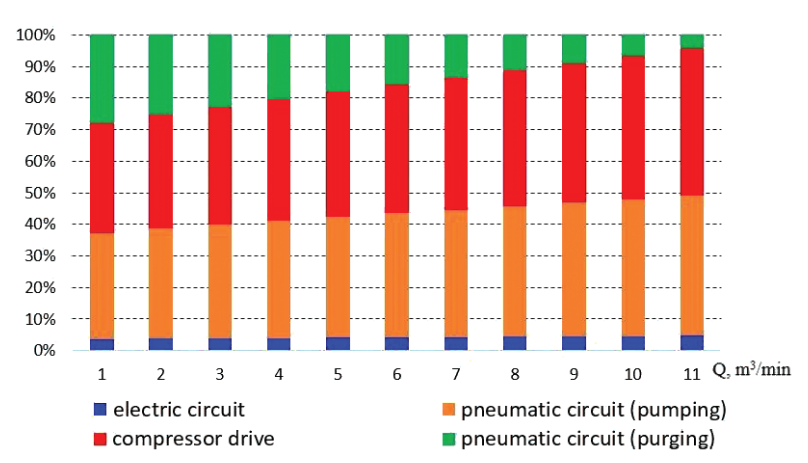

Fig. 1. Dependency graph of the relative energy dissipation in the elements of the electromechanical system vs. consumption level of pressurized air $Q$ 
ficiency. The dependence of efficiency change of the electromechanical system on the pressure level of pneumatic system $P_{\text {max opt }}$ in the interval of its change from $P_{\max }$ to $P_{\text {maxlim }}$ under different levels of pressurizer air consumption $Q$ (from $1-11 \mathrm{~m}^{3} / \mathrm{min}$ ) was determined [2, 8].

At the values of the upper limit of pressure $P_{\text {maxopt }}$, near $P_{\min }$, efficiency of the electromechanical system is low due to the impact of energy dissipation during start $E_{\text {start }}$. Further, as the value $P_{\max o p t}$ is increased, efficiency increases as well; this is due to reduction of energy dissipation in the pneumatic circuit when the pressure $\Delta E_{T N}+\Delta E_{T S}$ decreases. This trend holds until efficiency reaches its maximum value. Then efficiency decreases due to the incensement of energy dissipation in the pneumatic circuit during pressurized air pumping $\Delta E_{T N}+\Delta E_{T S}$ and in such elements like "drive-compressor".

It is obvious from the constructed dependence $\eta$ $\left(P_{\max }, Q\right)$ that it has an extreme, and it is a prerequisite for controlling the compressor's electric drive, and this will provide the maximum efficiency in each cycle of the two-step act by means of upper limit of pressure $P_{\max o t}$ regulation.

The optimization criterion was justified. It was offered to use analytic dependence of the efficiency of systems for production of pressurized air on the upper limit of pressure in the receiver $\left(P_{\max }\right)$ as a target function in in each cycle of the two-step act of the compressor' drive. It is necessary to ensure the maximum value of efficiency

$$
\eta\left(P_{\max }\right) \rightarrow \max
$$

Optimization problem is solved under constraints. They are the limits of pressure in the receiver

$$
P_{\text {min }}<P_{\text {max.opt }} \leq P_{\text {maxlim. }} \text {. }
$$

A limited frequency of starting for asynchronous motor per hour is

$$
M \leq M_{\text {lim }} .
$$

The determination of the target function's extreme value during the solution of the parametric optimization problem was made by scanning method. Optimal values of the target function's (efficiency) maximum at different dissipation levels of pressurized air by pneumatic receivers and considering constraints listed above [2].

Results of the study on electromechanical system operation parameters. The dependences of optimum levels of pressure Pmax opt on the air losses level $Q$ and efficiency values that correspond to $P_{\text {max opt }}$ are shown below (Figs. 2, 3). Dependence, shown in Fig. 3, shows that while the pressurized air losses level $Q$ increases, the system's efficiency level increases if values of pressure are equal to $P_{\max o p t}$.

However, dependence shown in Fig. 2 shows that the limit for a frequency of starting of asynchronous drive of the air piston compressor is active when pressurized air losses are equal to 0 to $9 \mathrm{~m}^{3} / \mathrm{min}$. That is why we came to the conclusion that high level of operation system efficiency can be reached at high level of pressurized air losses $Q$.

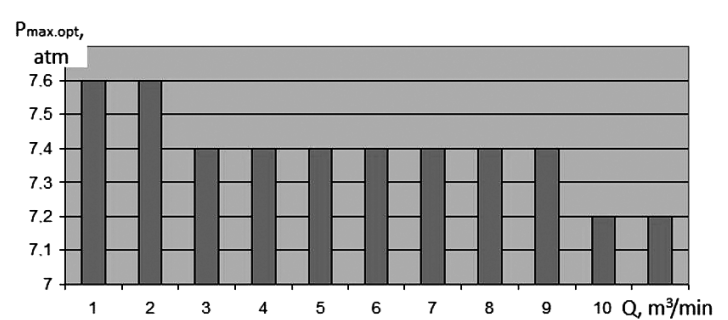

Fig. 2. The dependence of optimum upper levels of pressure $P_{\text {maxopt }}$ on the pressurized air losses level

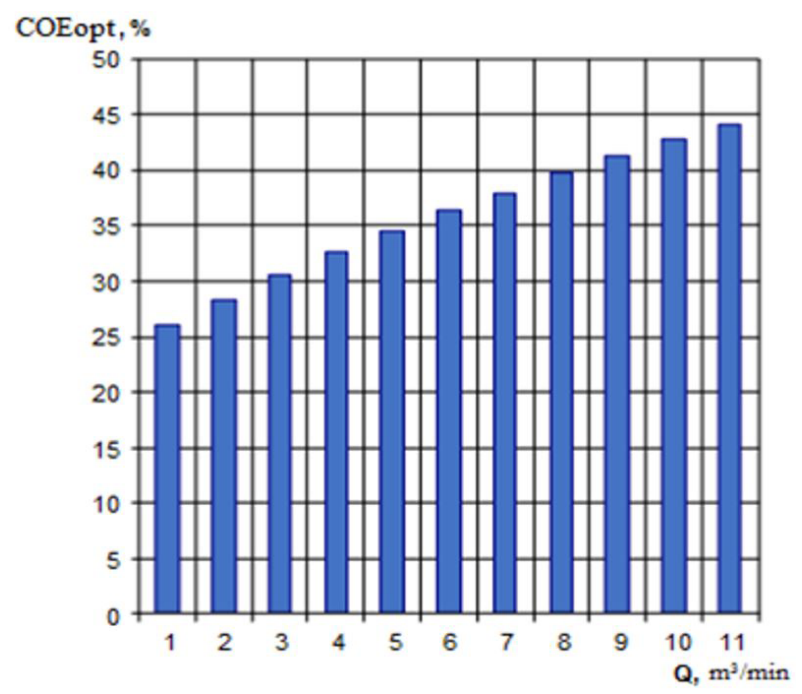

Fig. 3. The dependence of the system's efficiency level on the pressurized air losses level $Q$ at optimum values of $P_{\text {maxopt }}$

Discussion of the results of studies on pressurized air losses effect on the electromechanical system efficiency. Calculation of efficiency at optimum regime parameters shows that the increase in the pressurized air losses is accompanied by boost of the system's efficiency.

The solution of optimization problem enables to elaborate an effective method for controlling the compressor's electric drive [2].

A new method of two-step action of electric compressor was proposed.

The essence of the proposed method lies in the fact that in each cycle of two-step action of the compressor we should determine the level of pressurized air losses $Q$ and depending on its value set an optimal value of the upper limit of pressure in the receiver $\left(P_{\max o p t}\right)$, which provides the maximum level of efficiency $(\eta)$. Thus, the specific feature of the proposed method for controlling lies in the fact that the value of pressure $P_{\max }$ for each cycle of performance regulation is not constant and is changing in order to obtain maximum value of efficiency.

The problem of regime parameter optimization was solved for systems of different productivity. Albeit the difference of quantitative characteristics, the nature of the dependencies remained unchanged, confirming applicability of the developed method.

It was proved that when there are no restrictions on the frequency of starting, per hour (it increases to 
30-40) of the compressor's asynchronous motor at low levels of pressurized air losses (consumed by pneumatic receivers) it is possible to decrease the level of consumed energy. In a case of significant restriction on the frequency of starting (settled by nameplate data) power savings can be obtained only with considerable losses of pressurized air $Q$ (Fig. 4).

The performance simulation of operational regime of the electromechanical system for different options of the compressor's productivity management, namely: energy consumption of the electromechanical system during one hour according to the classic two-step action; by two-step action with optimal upper level of pressure; by applying two-step action with optimal upper level of pressure and given restrictions, had proved that the proposed method with changing upper level of pressure provides reduction of power consumption. In comparison with the classic two-step action, saving of up to $1-13 \%$ can be obtained.

The algorithm of controlling the electric drive of the compressor plant and circuit realization of the proposed method ware elaborated.

The features of the proposed algorithm are the following:

- it ensures definition of pressurized air dissipation by receivers, based on the rate of pressure change in the pneumatic circuit;

- it makes forecast of cyclic time of controlling $T_{c}$ and, consequently, the value of the upper level of pressure $P_{\max }$, based on the limit frequency of starting for asynchronous motor per hour;

- it provides a definition of energy dissipation in the elements of electrical complex and corresponding level of efficiency for the cycle at a given level of pressure $P_{\text {max }}$;

- it fulfills the selection of maximum efficiency $\left(\eta_{\text {opt }}\right)$ and the corresponding value of maximum pressure $P_{\text {maxopt }}$.

An experimental verification of regime parameters of the system, obtained according to the proposed model, was performed. Comparison of experimentally obtained values and the theoretical (simulation results) values shows that the computational error is less than $0.1-3 \%$. This comparison confirms the compatibility of the pro-

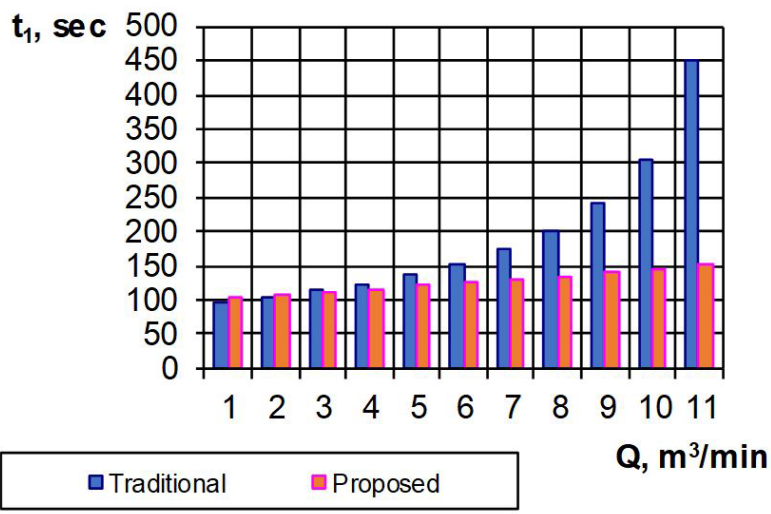

Fig. 4. The dependence of the compressor's "on" condition duration on pressurized air losses posed mathematical model to the original modeling problem.

Experimental studies have confirmed that for the proposed electromechanical systems at low levels of pressurized air dissipation the electric energy saving is almost absent, while at high levels of pressurized air dissipation it reaches $13 \%$.

Analysis of existing hardware of controlling of air piston compressor plants has shown that for the developed method for controlling it will be appropriate to apply the system based on the industrial program controller. It will not only provide continuous monitoring of necessary parameters (including pressure level), but also has other significant advantages in comparison with the relay system.

Implementation of the developed method for controlling piston compressor plants will allow saving energy at small levels of pressurized air dissipation $\left(1-8 \mathrm{~m}^{3} / \mathrm{min}\right)$ at average of 3 to 25 thousand UAH/year, and at significant levels $\left(9-11 \mathrm{~m}^{3} / \mathrm{min}\right)$ - from 40 to 85 thousand UAH/year.

Conclusions. Our research has helped to solve a scientific problem, which involves justification of the optimum operation of the electromechanical system for production and distribution of pressurized air and its realization by means of compressor drive controlling. The problem of parametric optimization of operational regimes for the electromechanical system was formulated and solved. It was proposed to use efficiency of electromechanical complex as a target function, and determine it for each cycle of two-step action of compressor drive. Constrains were imposed upon the frequency of starting of electric motor for some period of time and upon the level of air pressure in the pneumatic system. The essence of its solution involves the usage of possibilities of compressor drive controlling in order to improve energy efficiency of pressurized air transformation and distribution.

\section{References.}

1. Bobrov, A.V., 2017. The results of the analysis of methods for solving the optimization problem of the "electrical network - drive - compressor - pneumatic network" system. Mining Electrical and Automation, 98, pp. 11-22.

2. Bobrov, A. V. and Nesterova, O. Yu., 2017. Substantiation of controlled variables for energy management system of piston compressor units. Mining Electrical and Automation, 99, pp. 23-26.

3. Sadovenko, I., Rudakov, D. and Inkin, O., 2014. Geotechnical schemes to the multi-purpose use of geothermal energy and resources of abandoned mines. In: Progressive Technologies of Coal, Coalbed Methane, and Ores Mining. London: Taylor \& Francis Group, pp. 443-450.

4. Bondarenko, G. A. and Kyryk, G. V., 2016. Compressor plants. Sumy: Sumy State University.

5. Galdin, V.D., 2017. Ventilators and compressors. Omsk: SibADI.

6. Vodyanitskaya, N.I., 2013. Reciprocating Compressors. Odessa: Odessa State Academy of Refrigeration. 
7. Khoshimov, F. A. and Rakhmonov, I. U., 2015. Evaluation of the efficiency of the compressor stations of enterprises. Universum: Technical sciences: electronic scientific journals, 2(15), pp. 1-7.

8. Shechter, Y. L., Direktor, L. B. and Pruger, V. I., 2003. A simplified method for determination of the actual characteristics of piston compressors and air networks in enterprises. Promyshlennaya energetika, 8, pp. 18-19.

\section{Обгрунтування оптимальних режимів роботи електромеханічної системи виробництва та розподілу стислого повітря}

\section{О. В. Бобров ${ }^{1}$, Д. В. Ципленков ${ }^{2}$, А. М. Гребенюк ${ }^{2}$,} М. С. Кириченко ${ }^{2}$

1 - Коледж ракетно-космічного машинобудування Дніпровського національного університету імені Олеся Гончара, м. Дніпро, Україна, e-mail: alekseybob@ua.fm

2 - Національний технічний університет „Дніпровська політехніка“, м. Дніпро, Україна, e-mail: tsyplenkov.d.v@ nmu.one

Мета. Підвищення енергоефективності електромеханічної системи виробництва й розподілу стисненого повітря за рахунок застосування нового способу керування електроприводом компресорної установки.

Методика. Використано методи: параметричної оптимізації (сканування) - для вирішення завдання умовної оптимізації тривалості стану компресора на кожному циклі управління при різних витратах стисненого повітря; метод апроксимації вихідних даних електромеханічної системи; регресійний аналіз - при побудові нелінійної залежності продуктивності компресора та втрат стисненого повітря.

Результати. Розглянуті причини низької енергоефективності електромеханічної системи для виробництва й розподілу стисненого повітря на основі поршневого компресора. Проаналізовано взаємозв'язок і взаємовплив окремих елементів системи та режимів їх роботи. Аналіз рівнів розсіювання енергії в елементах електромеханічної системи проводився з метою вдосконалення методу керування електроприводом компресора шляхом застосування нових технічних рішень. Встановлені аналітичні залежності ККД від рівнів втрат енергії в окремих елементах системи та їі робочих параметрів при двоступеневому регулюванні потужності компресора. Побудована математична модель для розрахунку коефіцієнта ефективності електромеханічної системи. Завдання оптимізації параметрів роботи було сформульоване й вирішене з деякими припущеннями та обмеженнями за умови двоступеневого керування електроприводом компресора. Запропонована модель відрізняється від існуючих моделей можливістю обліку роботи режимів усіх елементів електромеханічної системи для визначення іiі енергетичного показника - коефіцієнта корисної дії. Запропоновані результати параметричної оптимізації режимів роботи електромеха- нічної системи для виробництва й розподілу стисненого повітря з різними рівнями його витрати.

Наукова новизна. Доведено, що зі зростанням продуктивності повітряних компресорів із запропонованим способом управління підвищується ККД системи в порівнянні 3 традиційним способом управління компресорами, що підвищує енергоефективність електромеханічної системи в цілому.

Практична значимість. Розроблено алгоритм контролю споживаної потужності компресора, що відтворює принцип визначення витрат стисненого повітря на основі вимірювання швидкості зміни тиску в його ресивері й дозволяє прогнозувати тривалість циклу управління.

Ключові слова: електропривод, компресор, електромеханічна система, стиснене повітря

\section{Обоснование оптимальных режимов работы электромеханической системы производства и распределения сжатого воздуха}

\section{А. В. Бобров ${ }^{1}$, Д. В. Цыпленков ${ }^{2}$, А. Н. Гребенюк ${ }^{2}$, М. С. Кириченко}

1 - Колледж ракетно-космического машиностроения Днепровского национального университета имени Олеся Гончара, г. Днепр, Украина, e-mail: alekseybob@ua.fm 2 - Национальный технический университет „Днепровская политехника“, г. Днепр, Украина, e-mail: tsyplenkov.d.v@nmu.one

Цель. Повышение энергоэффективности электромеханической системы производства и распределения сжатого воздуха за счет применения нового способа управления электроприводом компрессорной установки.

Методика. Использованы методы: параметрической оптимизации (сканирования) - для решения задачи условной оптимизации длительности состояния компрессора на каждом цикле управления при разных расходах сжатого воздуха; метод аппроксимации исходных данных электромеханической системы; регрессионный анализ - при построении нелинейной зависимости производительности компрессора и потерь сжатого воздуха.

Результаты. Рассмотрены причины низкой энергоэффективности электромеханической системы для производства и распределения сжатого воздуха на основе поршневого компрессора. Проанализирована взаимосвязь и взаимовлияние отдельных элементов системы и режимов их работы. Анализ уровней рассеяния энергии в элементах электромеханической системы проводился с целью усовершенствования метода управления электроприводом компрессора путем применения новых технических решений. Установлены аналитические зависимости КПД от уровней потерь энергии в отдельных элементах системы и ее рабочих параметров при двухступенчатом регулировании мощности компрессора. Построена математическая модель для расчета коэффициента эффективности электромеханической системы. Задача оптимиза- 
ции параметров работы была сформулирована и решена с некоторыми допущениями и ограничениями при условии двухступенчатого управления электроприводом компрессора. Предлагаемая модель отличается от существующих моделей возможностью учета работы режимов всех элементов электромеханической системы для определения ее энергетического показателя - коэффициента полезного действия. Предложены результаты параметрической оптимизации режимов работы электромеханической системы для производства и распределения сжатого воздуха с различными уровнями его расхода.

Научная новизна. Доказано, что с ростом производительности воздушных компрессоров с предложенным способом управления повышается КПД системы по сравнению с традиционным способом управления компрессорами, что повышает энергоэффективность электромеханической системы в целом.

Практическая значимость. Разработан алгоритм контроля потребляемой мощности компрессора, который воспроизводит принцип определения затрат сжатого воздуха на основе измерения скорости изменения давления в его ресивере и позволяет прогнозировать длительность цикла управления.

Ключевые слова: электропривод, компрессор, электромеханическая система, сжатый воздух

Рекомендовано до публікації докт. техн. наук С.І.Випанасенком. Дата надходження рукопису 19.02.18. 